\section{Alt og ingenting om hjerneslag}

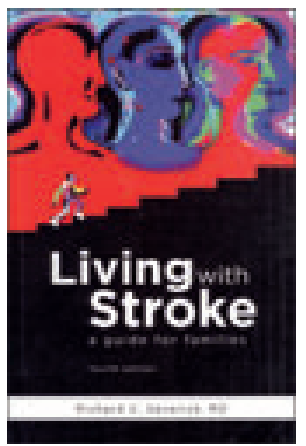

Richard C. Senelick

\section{Living with stroke}

A guide for families. 4. utg. 289 s, ill.

Birmingham, AL: HealthSouth Press, 2010

Pris USD 20

ISBN 978-1-891525-16-2

Forlaget HealthSouth Press eies av selskapet HealthSouth Corporation, som eier flere sykehus og poliklinikker i USA og tilbyr rehabilitering ved en rekke tilstander, bl.a. hjerneslag. Forfatteren er medisinsk direktør ved et av sykehusene i HealthSouth Corporation. Formålet med denne utgivelsen er å hjelpe pasienter og pårørende til å håndtere følgene av hjerneslag.

Det er fire deler. I den første delen gis informasjon om hjernen, hjerneslag, risikofaktorer og varselsymptomer. I den andre delen presenterer forfatteren symptomer ved hjerneslag og utredningen i den akutte fasen. Tredje del handler om profylaktisk behandling og rehabilitering etter fysiske, kognitive og emosjonelle skader av hjerneslag. I den fjerde delen retter forfatteren søkelyset mot behovene til de pårørende.

Den første delen er altså kortfattet innføring i hjernens anatomi og funksjoner, i patologi og kliniske uttrykk av hjerneslag. Her dekker forfatteren mange og store temaer på en overfladisk måte. Han bruker mange pasienteksempler og «folkelige» ord og uttrykk for å gjøre stoffet lettere forståelig, men ofte forkorter og forenkler han i den grad at man sitter igjen med en følelse av å ha fătt presentert «alt og ingenting». Samtidig faller forfatteren av og til for fristelsen til å benytte sjeldne, vanskelige ord, f.eks. prosopagnosia og aprosodia. Teksten ledsages i liten grad av illustrasjoner.

I de to neste delene presenterer forfatteren mange sider ved profylakse, diagnostikk, behandling og rehabilitering ved hjerneslag. Profylakse, diagnostikk og behandling presenterer han på en summarisk måte, og disse kapitlene vil neppe tilfredsstille den interesserte og nysgjerrige leser. Rehabilitering er derimot åpenbart forfatterens eget felt, og her skriver han innsiktsfullt og mer detaljert. Den siste delen om pårørendes behov inneholder også verdifulle synspunkter og anbefalinger.

Boken bærer preg av å være skrevet for amerikanske forhold, f.eks. oppgis det navn på amerikanske medisiner, diagnostiske tester som Functional Independence Measure, og behandlingsmetoder (Skills Acquisition Training), ofte med forkortelser (FIM, SAT). Enkelte av aktørene som er omtalt, spiller en liten rolle i vår norske hverdag. Det gjelder for eksempel forsikringsselskaper og såkalte Case Managers. Av største betydning er det imidlertid at enkelte av anbefalingene fraviker norske retningslinjer, eksempelvis anbefalingene om bruk av sentraltvirkende stimulerende midler og fremhevingen av sykehusbasert rehabilitering på bekostning av poliklinisk eller hjemmebasert rehabilitering. Anbefalingen av sykehusbasert rehabilitering er dessuten kontroversiell siden HealthSouth Corporation tilbyr nettopp dette. Endelig har språket en dramaturgi som passer dårlig for norske forhold, f.eks. omtales hjerneslag som «brain storm». De fleste litteraturkildene er gamle, og da hjelper det lite at Alf Brodal (1910-88) er sitert som en av få ikke-amerikanske forskere. Min konklusjon er at boken i liten grad når målet om å gi pasienter og pårørende nyttig kunnskap om hjerneslag. En leser uten forkunnskaper vil sannsynligvis finne stoffmengden overveldende og samtidig så forenklet at innsikten uteblir. Den interesserte eller kunnskapsrike leser vil sannsynligvis finne boken for overfladisk. Jeg kan derfor ikke anbefale den.

\section{Håndbok om hodepine}

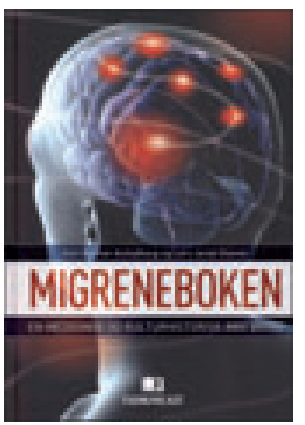

Karl Bjørnar Alstadhaug, Lars Jacob Stovner Migreneboken

En medisinsk og kulturhistorisk innføring. 402 s, tab, ill. Bergen: Fagbokforlaget, 2011. Pris NOK 579

ISBN 978-82-450-1147-0

Dette er en omfattende bok om hodepine med særlig vekt på migrene. Tittelen yter derfor ikke boken full rettferdighet. Målgruppen er fagfolk med noe medisinsk kompetanse, men også interesserte legfolk.

Boken er fint indeksert, og oppbygningen av de enkelte kapitlene er logisk. Forfatterne innleder mange kapitler med fine kasuistikker. Det er også mange gode illustrasjoner og tabeller som gjør teksten lettere tilgjengelig.

I innledningen nevner forfatterne spesialiserte tidsskrifter for hodepine, men her savner jeg Journal of Headache and Pain, som er det europeiske hodepineselskaps offisielle tidsskrift. Tabell 16.1 om faresignaler er lite spesifikk og derfor ikke så hjelpsom. Om flimmerskotom hadde det vært en hjelp om det allerede først i kapitlet var skissert at synsaura vanligvis er lysende sikksakkflimmer, som gradvis brer seg ut i den ene halvdelen av synsfeltet og som regel varer i 20 minutter. Dessuten burde det vært presisert at synsforstyrrelsene kan være forskjellige fra gang til gang.

Kasus 5 er fint, men det hadde vært hensiktsmessig med en samlet vurdering i appendiks tilsvarende en rekke andre kasuistikker, eller i det minste en sidehenvisning til der man kan finne svaret.

Anfallskalenderen er ikke spesifikk og til liten hjelp. Det finnes mange bra hodepinedagbøker, hvor spesifikke hodepinekarakteristika kan føres inn, hvilket gir mer presise opplysninger.

Alt i alt tror jeg boken kan være til stor nytte for både profesjonelle og andre interesserte. Jeg vil gi boken terningkast 5 .

Michael Bjørn Russell

Head and Neck Research Group

Forskningssenteret

Akershus universitetssykehus 